\title{
GROWTH OF AIN CRYSTAL USING REACTIVE SPUTTERING METHOD WITH VARIATION OF NITROGEN GAS PRESSURE AND SUBSTRATE TEMPERATURE
}

\author{
Dianita Wardani $^{1}$, Diah Susanti ${ }^{2}$, Agung Purniawan², Trimardji Atmono ${ }^{3}$ \\ 1) Politeknik Caltex Riau, Pekanbaru, Indonesia, dianitawardani@gmail.com \\ 2) Institut Teknologi Sepuluh Nopember (ITS), Surabaya, Indonesia \\ 3) Badan Tenaga Nuklir Nasional (BATAN), Yogyakarta, Indonesia
}

\begin{abstract}
ABSTRAK
PERTUMBUHAN KRISTAL AIN MENGGUNAKAN METODE REACTIVE SPUTTERING DENGAN VARIASI TEKANAN GAS NITROGEN DAN TEMPERATUR SUBSTRAT. Teknologi semikonduktor saat ini terus berkembang, baik dari segi penemuan material, teknik pembuatan, maupun implementasi dan pengembangannya. Pada penelitian ini, peneliti mensintesis AlN dengan menggunakan metode reaktif sputtering pada substrat $\mathrm{SiO}_{2}$ dengan variasi temperatur substrat $\left(200,250,300^{\circ} \mathrm{C}\right)$, dan tekanan gas nitrogen 10, 15 dan $20 \mathrm{mBar}$. Penelitian ini berhasil mensintesis nanomaterial AlN dengan sistem kristal heksagonal dan menunjukkan terbentuknya fase wurtzite. Sedangkan morfologi AlN yang terbentuk berbentuk elips dan lonjong. Pada penelitian ini diketahui bahwa menaikkan temperatur substrat menghasilkan morfologi yang lebih seragam dan homogen, kekasaran permukaan terbentuk dari 15,4 sampai $84 \mathrm{~nm}$ dan diperoleh ukuran kristal 64-87 $\mathrm{nm}$. Sedangkan penambahan tekanan gas nitrogen menyebabkan kristalinitas lebih baik. Penelitian ini menghasilkan AIN dengan tipe gelombang transversal optik dengan besar gelombang 600-670 $\mathrm{cm}^{-1}$. Pertumbuhan kristal AlN paling baik diperoleh pada parameter suhu substrat $290{ }^{\circ} \mathrm{C}$ dan tekanan gas nitrogen 20 mbar.
\end{abstract}

Kata kunci: Semikonduktor, aluminium nitrida (AlN), $\mathrm{SiO}_{2}$, Reactive Sputtering, Transversal Optik

\begin{abstract}
GROWTH OF AIN CRYSTAL USING REACTIVE SPUTTERING METHOD WITH VARIATION OF NITROGEN GAS PRESSURE AND SUBSTRATE TEMPERATURE. Today's semi-conductor technology continues to develop, both in terms of material discovery, manufacturing technique, as well as implementation and the development. In this research, the researcher will utilize the AlN synthesis with a reactive sputtering method on the substrate $\mathrm{SiO} 2$ that has done with variation substrate temperature of (200, $250,300 \circ$ C), and the nitrogen gas pressure of 10,15 and $20 \mathrm{mBar}$. This study successfully synthesize nanomaterial AlN with a hexagonal crystal system and shows the wurtzite phase is formed. While morphology AlN formed composed of particles - spherical shaped particles. From this research it is known that raising the temperature of the substrate produces more uniform morphology and homogeneous, the surface roughness is formed from 15.4 to $84 \mathrm{~nm}$ and obtained the crystal size is $64-87 \mathrm{~nm}$. While the addition of nitrogen gas pressure causes the better crystallinity. The research obtained AlN with Optical Transversal wave type at a wavenumber of 600-670 cm-1. The growth of AlN crystal growth of AlN is best obtained on the parameters of the substrate temperature $290^{\circ} \mathrm{C}$ and nitrogen gas pressure of 20 mbar.
\end{abstract}

Key words: Semiconductors, aluminum nitride (AlN), SiO2, Reactive Sputtering, Optical Transversal

\section{INTRODUCTION}

One of semi-conductor materials that attracts today's attention is Aluminum nitride (AlN). AlN is an important member of the group
III-V with the highest bandgap of around 6.2 $\mathrm{eV}$. It is a promising advanced ceramic material with many interesting properties, such as high 
electrical resistivity $\left(>10^{14} \Omega \mathrm{cm}\right)$, high thermal conductivity (285 W/(m.K) [1]. Therefore, AlN is a potential candidate for many applications on fusion fuel nuclear, solar cells, transparent conductive coatings, gas sensors, semiconductor materials well as electro and photoluminescence, Several methods of physical and chemical synthesis to produce AIN with a 1-dimensional nanostructures have been developed, including vapor phase method such as thermal evaporation, chemical vapor deposition, deposition of metal-organic vapor phase (MOCVD), electrodeposition and synthesis methods such solutions soles gel, solution deposition, hydrothermal synthesis, microemulsion technique, as well as direct growth 2 the solution of alcohol-aqueous[2], has been made to the process of formation of AlN, for example, the growth of product AlN can occur at temperatures $1300^{\circ} \mathrm{C}$ at a rate of 10 ${ }^{\circ} \mathrm{C} / \mathrm{min}$, using the technique of Vapor Liquid Solid (VLS) and using a stream of nitrogen gas [3]one of them is using the reactive sputtering method. This method has several advantages such as simple crystal growing technique, the deposition of low temperature and easy to control the experiment parameters [4].

\section{METHOD}

\section{Materials and Tools Research}

Silicon dioxide $\left(\mathrm{SiO}_{2}\right)$ with direction [100], Aluminum target material, Au target material, Ethanol solution, Acetone solution, Argon (Ar), Nitrogen $\left(\mathrm{N}_{2}\right)$, diamond cutting tool, Sputtering PSTA-Batan, Fourier Transform Infra Red (FTIR) and Transmission Electron Microscope (TEM) were used to characterized AlN.

\section{Sputtering Process $\mathrm{SiO}_{2}$ and Growing AIN on Substrates}

$\mathrm{SiO}_{2}$ as the substrate sputtered by sputtering using a $\mathrm{Au}$ catalyst uniform AlN growth on $\mathrm{SiO}_{2}$ substrates for 10 minutes. Time variable can be used in sputtering tool, among others, 1 minute or 2 minutes, depending on the needs. The function of the sputtering Au to give $\mathrm{SiO}_{2}$ layer on the substrate so that the ions of aluminum plates and nitrogen gas can attach and grow as a nanomaterial aluminum nitride. $\mathrm{SiO}_{2}$ substrates incorporated into the PVD chamber and placed in a holder that is prepared at the anode, while for the plates $\mathrm{Au}$ and $\mathrm{Al}$ is placed on the plate catoda. The first furnace chamber and in setting the sputtering deposition of $\mathrm{SiO}_{2}$ with $\mathrm{Au}$, is then subjected to vacuum for 15 minutes with great pressure Barr $4 \times 10^{-2}$ .Vacuum deposition substrate $\mathrm{SiO}_{2} / \mathrm{Au}$ conducted over 10 minutes.After the tool gives a chance for the target sputteringmaterial pure aluminum $(75 \mathrm{~mm})$ to the substrate surface $\mathrm{SiO}_{2}$ / Au with a deposition time of 15 minutes, without removing the substrate and the target material to remain in vacuum conditions. The devices are set to rise $10^{\circ} \mathrm{C} / \mathrm{min}$ to a temperature of 200,250 and $300^{\circ} \mathrm{C}$, then shalter the chamber is opened when the plasma is formed, then purged with nitrogen gas pressure variations nitrogen 10,15 and $20 \mathrm{mBar}$.

\section{RESULT AND DISCISSION}

\section{Fourier Transform Infra Red (FTIR) Analysis}

The purpose of testing Fourier Transform Infra Red (FTIR) is to identify a compound based on functional clusters. To determine the infrared absorption AlN compound that can be used in the application light emitted diode (LED). In this study, spectra of graphs showing different characteristics. FT-IR testing is done by using Shimadzu 8400 S test data obtained from the top of the chart obtained is at wavenumber range between $400-4000 \mathrm{~cm}^{-1}$.

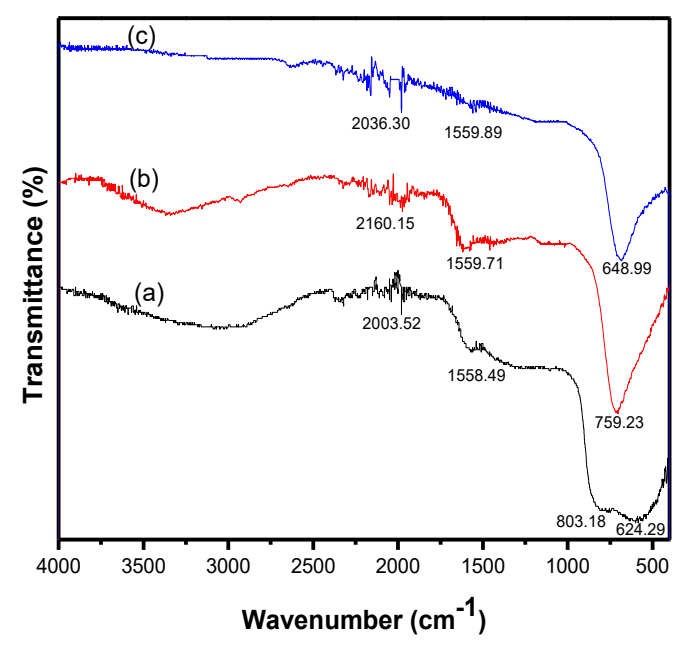

Figure 1. The results of Fourier Transform Infrared Spectroscopy (FT-IR) on the AIN substrate temperature to $250^{\circ} \mathrm{C}$ and pressure of nitrogen (a) $10 \mathrm{mBar}$ (b) $15 \mathrm{mBar}$ (c) $20 \mathrm{mBar}$ 
Figure 1 shows that, at a temperature of $250^{\circ} \mathrm{C}$ from the test results FT-IR peak have varied from $97-99 \%$ transmittance in the range of $600-800 \mathrm{~cm}-1$ are almost the same as the previous variation which indicates the downward peak beam then forwarded and absorbed the higher. According to the results of testing of FTIR, AlN compounds generated in this study can be applied to light emitted diode (LED). AlN compound capable of transmitting visible light at a wavelength of $600-800 \mathrm{~cm}-1$. Wave AlN compounds are inorganic compounds (Fei et al, 2012). From the research results can be seen that the dominant wavelegths formed at intervals of $600-800 \mathrm{~cm}^{-1}$. In wavenumber interval $600-670$ an optical transverse force active infrared and visible AlN compound produces infrared optical properties of the active transverse to the parameter variations in temperature to $250^{\circ} \mathrm{C}$ in nitrogen pressure $20 \mathrm{mBar}$.

In accordance with characterization LED that can emit electromagnetic waves, the compounds can be applied in a window AlN layer of the LED. At the peak absorption region of 2000-2200 cm-1, there are other weak peak was observed that the vibration mode of bonds $\mathrm{N}-\mathrm{Al}-\mathrm{N}$, it further confirms that growth over $\mathrm{SiO} 2$ are stoichiometric AlN substrate [5]. For the $\mathrm{C}-\mathrm{O}$ bond bending measured the impurities from the air were identified during the measurement process. It also deals with the homogeneity of crystals that can improve the optical properties where the target is deposited uniformly and relatively the same, making the level of crystallinity the better, so as to boost the value of transmission [6].

\section{Transmission Electron Microscope (TEM) Analysis}

Testing Transmission Electron Microscope (TEM) was used to analyze the morphology, crystal structure and composition of the specimen. TEM provides higher resolution than SEM and can facilitate the analysis of the size of the nanomaterial. TEM testing in this study was conducted using a JEOL JEM-1400 and conducted at the Laboratory of Chemistry, University of Gajah Mada, Yogyakarta.

TEM imaging results in Figure 2 (a) show that AlN formed a nanomaterial with magnification scale of $100 \mathrm{~nm}$ and $20 \mathrm{~nm}$, for parameter $300^{\circ} \mathrm{C}$ substrate temperature and nitrogen pressure $20 \mathrm{mBar}$ on measurements obtained $\pm 64-87 \mathrm{~nm}$ size. On the results of the previous morphological observations performed with the SEM imaging shows the morphology of AlN obtained less clear. In the picture TEM imaging can we know that the round-shaped particles which tend to merge so that oval and elongated.

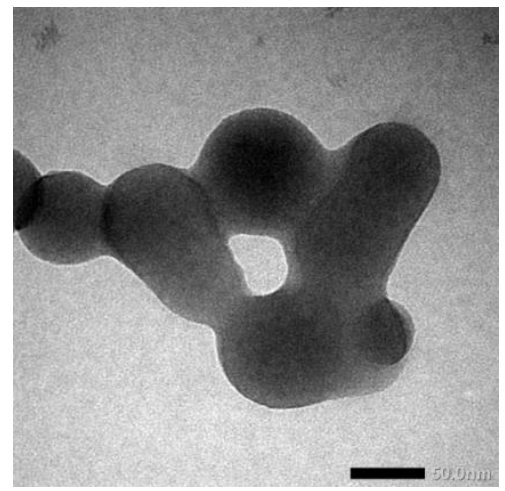

(a)

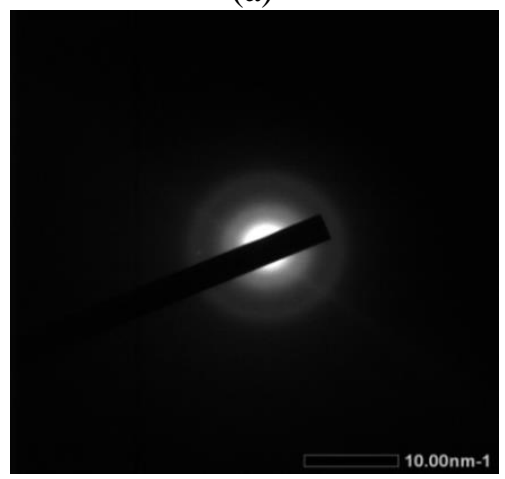

(b)

Figure 2 The results of TEM imaging at $300^{\circ} \mathrm{C}$ Substrate Temperature Variation and Nitrogen pressure $20 \mathrm{mBar}$

(a) Magnification Scale 30.000x with $50 \mathrm{~nm}$ and (b) Test Results SAED pattern Diffraction Ring.

Figure 2 (b) shows the test results SAED, for analysis of the results diffraction pattern obtained one point in the ring, after the calculation of the value of $\mathrm{d}$-spacing. The results of the calculations show that the value of diffraction d-spacing is 1.38163 in the notation field (200). The result is worth almost the same as the value of d-spacing of XRD test results is 1.35653 in the field (200). XRD characterization results have a peak in 3 dominant fields, represented by field (101) at $2 \theta=38.758^{\circ}$, field $(103)$ at $2 \theta=65.443^{\circ}$, field (200) at $2 \theta=69.40^{\circ}$. For the highest peak intensity result at $2 \theta=69.40^{\circ}$, with a match JCPDF03-1144. 


\section{CONCLUSIONS}

Based on the research that has been done, it can be concluded that the synthesis of compounds of aluminum nitride (AIN) has been successfully performed using reactive sputtering over $\mathrm{SiO}_{2}$ substrate. Of the various substrate temperature and nitrogen pressure this study we concluded that, AlN compound of testing Fourier Transmission Infrared (FTIR) showed wavenumber $600-800 \mathrm{~cm}^{-1}$, for the FTIR results wavenumber of $600-670 \mathrm{~cm}^{-1}$ is the Optical Transversal. TEM results of the tests show that AlN formed a nanomaterial size 64$87 \mathrm{~nm}$.

\section{REFERENCES}

1. Shi, Zhongqi Shi (2014). "Combustion synthesis of AlNnanowhiskers with differentmetallic catalysts" Journal of Crystal Growth, 323:286-289.

2. Yoon, Jong-Hwan. (2014). "Alternative vapor-liquid-solid process in Au-assisted growth of silica nanowires". Materials Letters, 123:131-134.

3. Yu, Leshu, Lv, Y., Zhang, X., Zhang, Y., Zou, R., dan Zhang, F. (2011). "Vapor-liquid-solid growth route to AlN nanowires on Au-coated $\mathrm{Si}$ substrate by direct nitridation of $\mathrm{Al}$ powder". Journal of Crystal Growth, 334:57-61.

4. Wei, Z.Q., Zhang, (2014). "Effects of sputtering pressure on nanostructure and nanomechanical properties of AlN films prepared by RF reactive sputtering", Vol 2, 2845-2855.

5. Mortet, V dkk (2003). "Aluminium nitride films deposition by reactive triode sputtering for surface acoustic wave device applications". Surface Coatings and Technology. 176:88-92

6. Planck Van, R. P. Devaty, And W. J. Choyke,(2009) "Infrared Reflectance Of Thin Aluminum Nitride Films On Various Substrates", Appl. Phys. Lett., Vol. 62, Pp. 750-752. 